\title{
Competitive strategies of Small Independent Retailers
}

\author{
Fabien Eymas \\ Maître de conférences, CREGO, Université de Haute-Alsace \\ Faouzi Bensebaa \\ Professeur, LED, Université Paris 8 Vincennes - Saint-Denis
}

\begin{abstract}
Despite the critical role given to small independent retailers (SIRs) in the revitalisation of city centres, little knowledge exists about their actual competitive strategies. Existing literature rather is normative, recommending SIRs to focus on customer orientation. Thus, the aim of this study is to identify the types of competitive strategies really adopted by SIRs. This qualitative study is based on 13 semi-structured interviews of the booksellers, beer and wine merchants we met around Paris (France) in 2018. Data analysis was conducted in two stages: each interview was coded to bring out themes, which were then linked in cognitive maps. Five types of SIRs' competitive strategies emerged from the study, depending on their main focus of attention. Either SIRs have no weapon to fight against external factors and they suffer competition, or they have limited means and focus on their relationship with customers, or even they possess a specific resource they can rely on (innovative character, skills, values) to go beyond ordinary customer orientation. The typology should be a useful tool for SIRs interested in competitive strategies and for municipalities looking for new insights to succeed in the revitalisation of their city centres. Revitalisation of city centres is a big challenge for many Western cities, especially small and middle-size ones. To the best of our knowledge, the typology that comes from this study is the very first one on SIRs. Theoretically, it may help organize researches on SIRs' competitive strategies. Pragmatically, it provides a better understanding of SIRs' competitive strategies.
\end{abstract}

\section{Keywords}

Competitive strategy, customer orientation, small independent retailer.

\section{Introduction}

The 2018 balance sheet of the "French Fédération pour l'urbanisme et le développement du commerce spécialisé" is clear. The activity of specialised trade is declining: it fell to $3.3 \%$ across France and all types of areas were affected, peripheries as well as city centres (Bicard, 2019). These 
mediocre results did not come as a surprise, as retail has been facing difficulties since the 1990's (Moati, 2016), especially in small and medium-sized cities (Delage et al., 2020). This difficult situation for physical retail is not specific to France, but a common problem in the Western world (Badot et al., 2018). In the United States, for example, 9000 retail stores shut down in 2019 (Lesnes, 2020). This decline is said to be the consequence of multiple factors, such as the fact that consumers spend less money, the inexorable growth of digital trade or the emergence of alternate ways of consuming (Badot et al., 2018). These difficulties especially affect small independent retailers (SIRs) who have to compete with more profitable retail chains (Kfoury and Trevien, 2017) and who are rather located in city centres which suffer from the competition of suburban malls and from a lack of global management (Padilla and Eastlick, 2009). Even if SIRs benefited, at least at the very beginning, from the Covid-19 pandemic (Li et al., 2020), the situation remains critical in some small and medium-sized cities (Chocron, 2020).

However, despite the crucial part that the environment of the SIRs seems to play in their success, some internal factors to SIRs, such as customer orientation (Tajeddini et al., 2013) or the relationships that they maintain with their suppliers (McGuiness et Hutchinson, 2013; Praharsi et al., 2014) have been identified as keys to their prosperity. In fact, most of the studies about SIRs' competitive strategies are normative and try to identify what is the best attitude to adopt (Grimmer et al., 2018; Lin, 2016). Notwithstanding the importance of SIRs in the revitalisation of city centres (Padilla and Eastlick, 2009), few characteristics of their competitive strategies have been identified: they adopt a niche strategy (Watkin, 1986) and provide unique products with better service (Armstrong, 2012; Barber et Tietje, 2004; Coca-Stefaniak et al., 2010). Moreover, existing typologies based on competitive strategies show that large firms respond differently to environmental change (Miles and Snow, 1978; Moore, 2005). In the end, the competitive strategies that SIRs really adopt remain largely unknown.

Thus, the aim of this study is to better understand SIRs' actual competitive strategies. To this end, research to answer the following question has been conducted: what type of competitive strategies do urban SIRs adopt to face the multiple forms of competition they have to deal with? The answer is based on the analysis of the interviews the authors conducted with 13 SIRs.

In the first section, a review of prior studies on SIRs is drawn, showing the differences of conclusion about factors impacting their competitive strategies. The second is devoted to the presentation of the methodology. The results of the research that led to the very first typology of SIRs are presented in the third section. In the fourth section, this typology of SIRs is discussed and the implications and limitations of the study are exposed. 


\section{Theoretical background}

To draw this literature review, studies about SIRs' competitive strategies were collected on different data bases (e.g. Emerald, Wiley, etc.). They are scarce. In their survey, Runyan and Drodge (2008) counted 14 papers on the topic and only a few more have been written since. If most of them aim at linking SIRs' competitive strategies with their performance, highlighting customer orientation as their main key to success, a few others deal with the characteristics of SIRs' competitive strategies.

\subsection{Characteristics and variables of actual SIRs' competitive strategies}

SIRs' competitive strategies have a few distinctive traits. To face competition from mass distribution and chains, they adopt a niche strategy (Watkin, 1986), provide unique, high quality products or services, as well as better service (Armstrong, 2012). In addition, they offer their customers a better atmosphere and better services than chains and mass distributors (Barber and Tietje, 2004). Furthermore, SIRs develop a "localisation" strategic marketing approach characterized by community embeddedness, place attractiveness, importance of word-of-mouth and interpersonal relationships between executives and their customers allowing a level of customer service beyond simple product advice (Coca-Stefaniak et al., 2010).

SIRs' competitive strategies also depend on some variables. Four ways to adapt to environmental change can be distinguished (Miles and Snow, 1978). While defenders focus on a narrow segment and try to prevent competitors from entering, prospectors are rather aggressive, always seeking new opportunities to exploit. Analysers combine both previous types according to their analysis of the situation and reactors respond inappropriately. Only three of the four types are present in retail (Moore, 2005): prospectors, reactors and a mix between defenders and analysers which appear difficult to discriminate. But this study applies to retail chains, and Smith et al. (1986) showed that small firms couldn't be prospectors because of their limited resources.

Besides, the type of strategy defined is affected by the type of store and its age (Kean et al., 1996), the ambition of executives, their ability to differentiate their offer, their degree of appropriation of the geographic positioning and their level of understanding of the market and the environment (Ringwald and Parfitt, 2011).

SIRs' competitive strategies could as well be influenced by the specific characteristics of small enterprises (SE). SEs' executives' geographic origin and background have consequences on their level of embeddedness in the territory in which they established their business (Watts et al., 2006). In addition, differences in gender (Buttner and Moore, 1997), as well as in goals (Reijonen and Komppula, 2007) lead SEs' executives not to use the same criteria to measure the success of their 
business, which, therefore, draws different competitive strategies. Last but not least, their human and social capital allows them to create strategic spaces (Jones et al., 2010), which means that they have a direct impact on the SE's competitive strategies.

1.2. Customer orientation as the key to successful competitive strategies for SIRs Most of the researches on SIRs' competitive strategies aim to identify the factors conducive to their success. First, clearly defined (Conant et al., 1993) and planned (Praharsi et al., 2014) strategies are associated with better performance. Then, the characteristics of products marketed are emphasised as success factors. Therefore, the proposal of a targeted assortment of differentiated products (Paige and Littrell, 2002) as well as the knowledge allowing to obtain supplies from quality suppliers (McGuiness and Hutchinson, 2013) appear as vectors of performance. More generally, the relationships between SIRs and their suppliers are presented as performance factors (Praharsi et al., 2014). Besides, innovation seems to favour the success of SIRs (Bhaskaran, 2006; Lin, 2016). More recently, SIRs' business information system and their access to financial capital have been linked with the performance of their business (Grimmer et al., 2018). Furthermore, the success of SIRs depends on the customer service provided (Merlo et al., 2006), which should be of a high standard (Ellis and Kelley, 1992) or unique (Paige and Littrell, 2002). Moreover, loyalty programs are also vectors of success for SIRs (Praharsi et al., 2014).

Above all, two concepts aim to integrate several performance factors: customer orientation and market orientation. A customer-oriented company primarily takes decisions and actions under its customers (Spillan and Parnell, 2006). In fact, customer orientation appears as a traditional key concept of marketing (Kotler, 2003) and service management (Vargo and Lusch, 2004). It is mainly seen as the key to any business success (Pekovic and Rolland, 2016; Slater and Narver, 1994). If market orientation incorporates both competitor and customer intelligence (Kajalo and Lindblom, 2015), customer orientation however constitutes its main pillar (Pelham, 2000). Both customer (Tajeddini et al., 2013) and market orientations (Kara et al., 2005; Megicks and Warnaby, 2008) have been put forward as ways of performance of SIRs in particular, even if the role of market orientation might only be indirect (Kajalo and Lindblom, 2015). In line with the customer orientation perspective, the relationships that SIRs maintain with their customers are said to be privileged over those that they sustain with their suppliers, insofar as relations with the latter do not seem to improve their ability to respond quickly to the customers' needs (Adjei et al., 2009).

\subsection{Conceptual framework}


To identify SIRs' types of competitive strategies, a conceptual framework is drawn on the perspective of the competitive dynamics (Chen and Miller, 2012; 2015). This current considers both external (Porter, 1980) and internal (Barney, 1991; Peteraf, 1993) factors affecting competitive strategies. On the one hand, external factors such as the competition of larger firms like retail chains and mass distributors (Watkin, 1986) or government policies (Erkip and Ozuduru, 2015; Hallsworth and CocaStefaniak, 2018; Kim et al., 2018) seem to influence SIRs' competitive strategies. On the other hand, as the literature we have reviewed above shows, internal factors also affect SIRs' competitive strategies. Considering the context of a fast-changing hypercompetitive environment (D'Aveni, 1994), the competitive dynamics perspective integrates the dynamic nature of competition through the concept of interaction (Chen and Miller, 2012). Concretely, competitive strategy materializes in three types of interactions between the firm and its stakeholders: rivalrous, coopetitive and relational (Chen and Miller, 2015). The first two describe the relationships between competitors, whereas the relational interaction allows to integrate the links a firm has with its other stakeholders. Moreover, competitive dynamics acknowledges that both external and internal factors are filtered by the actors' perception (Chen and Miller, 2012), which is congruent with studies concluding that cognitive differences between SE's executives make them adopt various types of strategy (Armstrong and Hird, 2009; Fassin et al., 2011).

Figure 1. Conceptual model of SIRs' competitive strategies (source: authors)

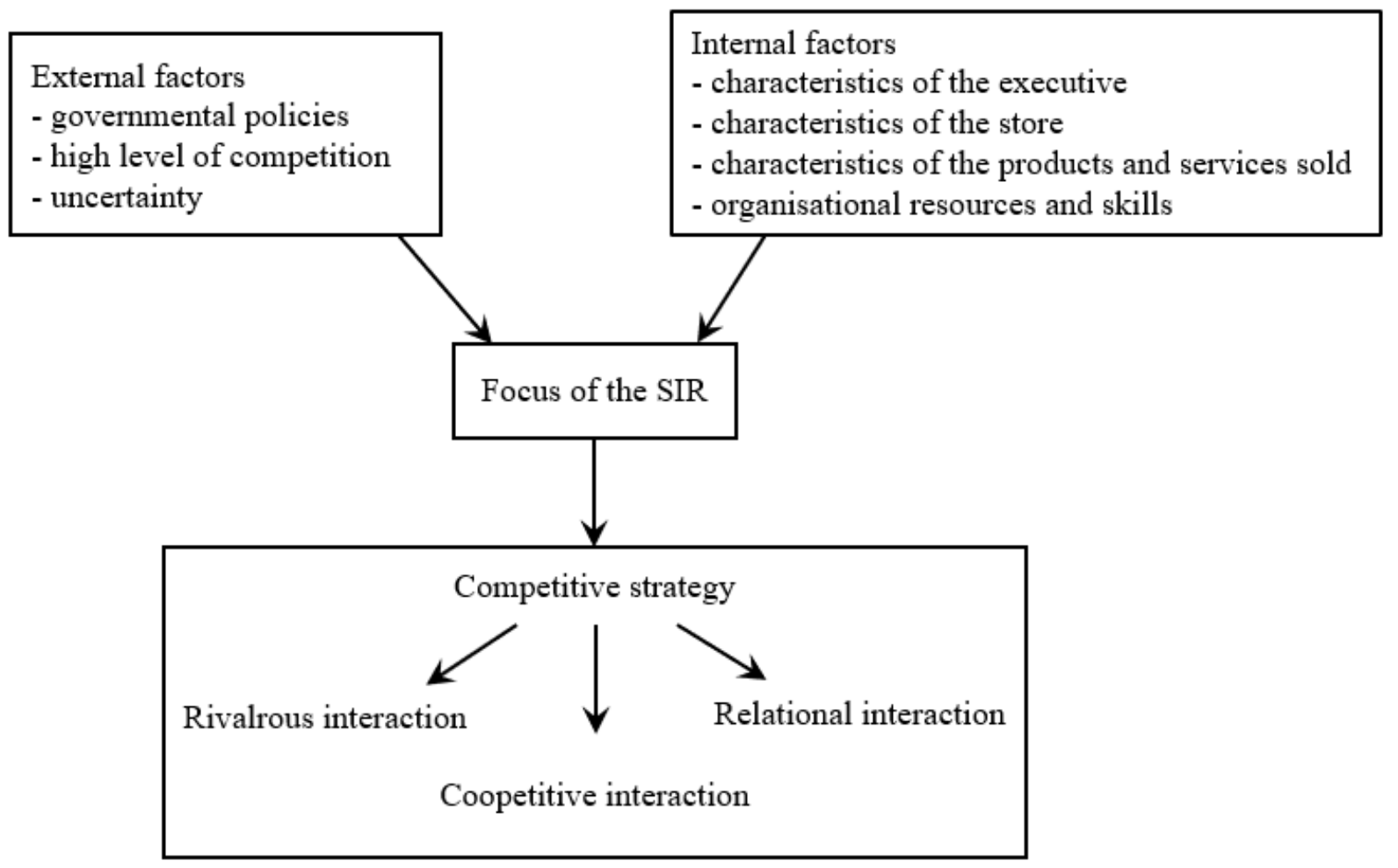


In the end, the emphasis on customer orientation of existing literature implies that interactions with customers have to be in the heart of SIRs' competitive strategies for them to be successful. However, literature also shows that different factors and their perception by SIRs affect their competitive strategies, suggesting that other interactions as well as external or internal factors could play an important part in SIRs' competitive strategies. Differences in the focus of SIRs could then lead to various competitive strategies, which raises the question of the existence of distinct types of competitive strategies.

\section{Methodology}

To identify the types of competitive strategies SIRs really adopted to face competition, a qualitative study appeared appropriate. Indeed, the use of interviews allows the participants to express all the richness of their experiences (Janssen et al., 2018). In this section, after presenting how participants were selected, both data collection and analysis are detailed.

\subsection{Participant selection}

The participants (11 men and 2 women) were chosen in a combination of convenience and purposive ways (Patton, 2015). The sample is mainly purposive as the interviewees had to meet three criteria. First, obviously, they had to be SIRs. Second, in order to lower the influence of the environment on their type of competitive strategies, they had to evolve in the most neutral environment: neither too constraining, nor favourable. Close suburbs of Paris appeared to be a good balance (Bessière and Trevien, 2016). Third, interviewing different types of SIRs allowed to explore contexts with varied external factors and increase the internal validity of the study (Yin, 2012). The sample is also convenient, because among the hundred or so SIRs approached, only those who accepted were interviewed. It led us to meet types of SIRs that are quite numerous, as we met in the end 2 beer merchants (executives 2 and 10), 4 booksellers (executives 3, 4, 8 and 13) and 7 wine merchants (executives 1, 5, 6, 7, 9, 11 and 12). None of them employed more than 5 people and they had created or taken over their business for a wide variety of periods, ranging from 1 to 18 years.

\subsection{Data collection}

Semi-structured interviews enabled us to understand what really mattered for them when it comes to competitive strategy. The average duration of the interviews was about 36 minutes. Participants were first invited to tell how they got to the situation they were in at the time of the interview: when and why they decided to start their business, why this type of business, why this location. They were then 
asked to describe how their business had evolved since it had started. Last but not least, they answered questions about competition such as: "what does competition mean for you?", "who are your competitors?" or "what do you do to compete?" These questions were deliberately general to leave the participants a lot of freedom to talk about what they spontaneously related to competition. 13 interviews had to be conducted until the point of theoretical saturation appeared manifest (Glaser and Strauss, 1967).

\subsection{Data Analysis: from coding to cognitive maps}

Themes the executives related to competition emerged from descriptive and sub- coding (Miles et al., 2019) and we linked them to each other by drawing cognitive maps. As the true meaning of categories and concepts comes from their links to each other, cognitive maps appear to be good tools to faithfully represent the ideas expressed by the participants (Cossette, 2002). On the map drawn Figure 2, we see that both external - indirect competition, market booming - and internal - experience - factors led the SIR to embark on a competitive strategy which consists in exploiting the concept he had designed, made of a cosy atmosphere, local delivery, tasting area, etc.

Figure 2. Cognitive map of the competitive strategy of the executive 2 (source: authors)

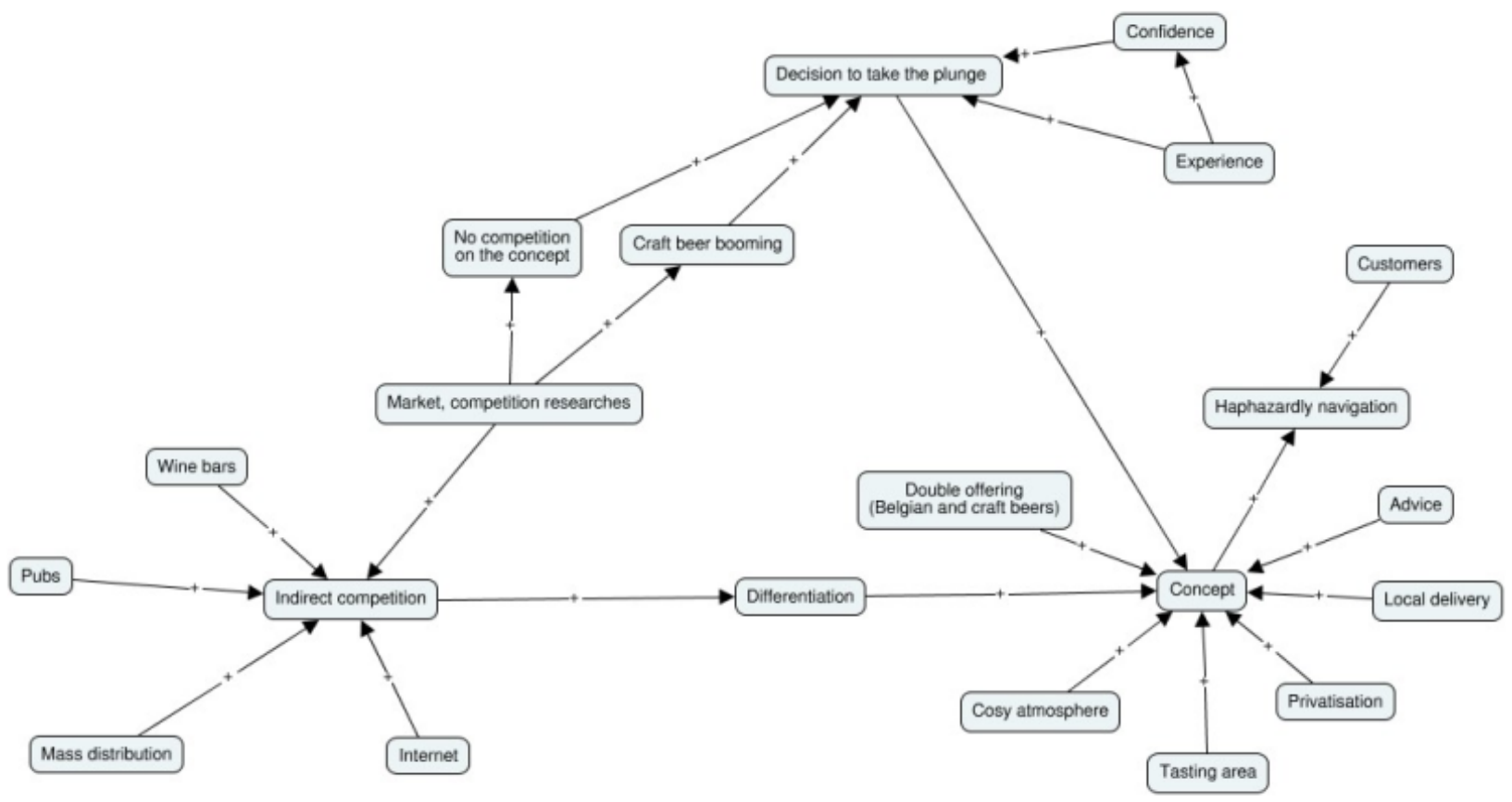

The analysis of the maps was conducted by identifying the most important concepts to the participants (Eden, 2004), which amounts to highlight their main focus of attention. These were those 
with the highest number of incoming and outgoing arrows. As these central concepts were thus taken out of their context, we created the 'central relationships' exposed in Table 1 to reveal the nature of the links between central concepts.

Table 1. Concepts et central relations of cognitive maps (source: authors)

\begin{tabular}{|c|c|c|c|}
\hline Executive & Central concepts & $\begin{array}{c}\text { Number of } \\
\text { arrows }\end{array}$ & Central relations \\
\hline 1 & $\begin{array}{l}\text { Differentiation } \\
\text { Customer loyalty }\end{array}$ & $\begin{array}{l}7 \\
5\end{array}$ & $\begin{array}{l}\text { The executive implements a differentiation } \\
\text { strategy in order to enhance customer loyalty }\end{array}$ \\
\hline 2 & $\begin{array}{l}\text { Concept } \\
\text { Indirect competition } \\
\text { Decision to take the } \\
\text { plunge }\end{array}$ & $\begin{array}{l}9 \\
6 \\
5\end{array}$ & $\begin{array}{l}\text { The executive created a concept that allows } \\
\text { him to avoid direct competition }\end{array}$ \\
\hline 3 & $\begin{array}{l}\text { Competition } \\
\text { Loyalty }\end{array}$ & 7 & $\begin{array}{l}\text { To face competition, the executive focuses on } \\
\text { customer loyalty }\end{array}$ \\
\hline 4 & $\begin{array}{l}\text { Struggle } \\
\text { High level of competition } \\
\text { Difficulties }\end{array}$ & $\begin{array}{l}7 \\
6 \\
4\end{array}$ & $\begin{array}{l}\text { The executive struggles as he can in order to } \\
\text { face competitors that bring him problems }\end{array}$ \\
\hline 5 & $\begin{array}{l}\text { Skills } \\
\text { Reputation }\end{array}$ & $\begin{array}{l}6 \\
4\end{array}$ & $\begin{array}{l}\text { The executive relies upon her skills and } \\
\text { reputation to make her business grow }\end{array}$ \\
\hline 6 & $\begin{array}{l}\text { Loyalty } \\
\text { Pleasure } \\
\text { Product of quality }\end{array}$ & $\begin{array}{l}6 \\
6 \\
6\end{array}$ & $\begin{array}{l}\text { The executive enjoys relaying products of } \\
\text { quality to his customers }\end{array}$ \\
\hline 7 & $\begin{array}{l}\text { Supplier selection } \\
\text { Skills } \\
\text { Growing segment }\end{array}$ & $\begin{array}{l}5 \\
4 \\
4\end{array}$ & $\begin{array}{l}\text { The executive mobilises its skills } \\
\text { (commercialisation, marketing, selection) to } \\
\text { take advantage of a high growing segment }\end{array}$ \\
\hline 8 & Customers & 6 & $\begin{array}{l}\text { Despite being focused on its customers, the } \\
\text { executive appears quite passive }\end{array}$ \\
\hline 9 & $\begin{array}{l}\text { Funding problems } \\
\text { Modern wine merchant } \\
\text { Customers } \\
\text { Home delivery } \\
\text { Winemakers }\end{array}$ & $\begin{array}{l}8 \\
7 \\
5 \\
5 \\
5\end{array}$ & $\begin{array}{l}\text { The executive tries to develop a concept of } \\
\text { modern wine merchant (distribution } \\
\text { ecosystem, delivery, higher size), but its small } \\
\text { size prevents him from finding the fund he } \\
\text { needs to grow and generates suppliers' mistrust }\end{array}$ \\
\hline 10 & $\begin{array}{l}\text { Customers } \\
\text { Store } \\
\text { Growth }\end{array}$ & $\begin{array}{l}6 \\
5 \\
4\end{array}$ & $\begin{array}{l}\text { In a sector with low competition, the executive } \\
\text { has a concept that assures him both customers } \\
\text { and growth perspective }\end{array}$ \\
\hline 11 & $\begin{array}{l}\text { Loyalty } \\
\text { Concept }\end{array}$ & $\begin{array}{l}7 \\
5\end{array}$ & $\begin{array}{l}\text { The executive develops a concept designed for } \\
\text { his own needs to enhance the customers' } \\
\text { loyalty }\end{array}$ \\
\hline 12 & $\begin{array}{l}\text { Natural products } \\
\text { Executive's values }\end{array}$ & $\begin{array}{l}5 \\
4\end{array}$ & $\begin{array}{l}\text { The executive seeks to promote products that } \\
\text { match his ecologist values }\end{array}$ \\
\hline
\end{tabular}




\begin{tabular}{|c|l|l|l|}
\hline 13 & $\begin{array}{l}\text { Customer loyalty } \\
\text { Attracting customers }\end{array}$ & 8 & $\begin{array}{l}\text { In a sector with low competition, the executive } \\
\text { tries to attract new customers and to enhance } \\
\text { their loyalty }\end{array}$ \\
\hline
\end{tabular}

\section{Findings}

This research shows that customer and market orientations are not mandatory competitive strategies for SIRs to last in time, they use other strategic options, which allows us to draw a typology.

\subsection{Customer and market orientations are not always the main concerns of SIRs}

Cognitive maps reveal that customer and market orientations are not generalized strategies among the SIRs that we met. When it comes to competitive strategy, SIRs mainly either focus on relational or rivalrous interactions or on internal factors. Besides, some SIRs who are primarily paying attention to relational interactions are rather centred on the relationship they foster with their suppliers than with their customers. Those who first focus on internal factors to perform their competitive strategies concretely concentrate on the original concept they have created or on their above-the-average skills.

\subsection{A typology of SIR's competitive strategies}

This typology is based on the main focus of attention of the SIRs when it comes to competitive strategy. Five types of competitive strategies emerged, they are presented in Table 2.

Table 2. The 5 SIR's competitive strategy-types (source: authors)

\begin{tabular}{|l|l|c|}
\hline Ways to competitive advantage & Type of competitive strategies & Executives \\
\hline Reacting to external factors & The Survivor & 4 \\
\hline Focusing on the concept created & The Visionary & $2,9,10,11$ \\
\hline $\begin{array}{l}\text { Focusing on customers relying } \\
\text { on internal factors }\end{array}$ & The Classic & $1,3,8,13$ \\
\hline Making good use of its skills & The Skilled & 5,7 \\
\hline $\begin{array}{l}\text { Selecting suppliers in line with } \\
\text { its values }\end{array}$ & The Activist & 6,12 \\
\hline
\end{tabular}

The Classic SIR. Classic SIRs created or took over their business in quite a competitive sector. Seeking to make a living from their work rather than grow, Classic SIRs chose their activity because they had some attraction to it, even a genuine passion sometimes, or because they seized a business opportunity. 
"It's a job that we do out of passion." (Executive 3)

In this context, Classic SIRs devote their energy to creating a customer base and then retaining it. They demonstrate the customer orientation that is expected in every SIR's competitive strategy, that's why we call them "classic".

"This loyalty strategy, I implemented it as soon as I arrived 10 years ago." (Executive 3)

Relational interactions Classic SIRs have with their customers appear to be the leading thread of their competitive strategy. To implement this strategic orientation, they rely on internal factors, working, for example, on the atmosphere of the store, on the quality of their advice or on in paying attention to their customers' needs.

"With loyal customers, we talk. Sometimes they tell us: 'I started this, I haven't finished.' We don't know, we order the rest, we order the beginning to discover. [This is one way] to renew the fund." (Executive 13)

The Activist SIR. Activist SIRs also appear to be executives who want to make a decent living from their work, rather than grow at all cost. But above all, Activists chose an activity allowing them to promote products that they particularly appreciate, products that correspond to their values.

"I can’t sell [anything]. I would never sell hormone chicken here. It is very clear." (Executive 6)

Through the commercialisation of products that they carefully selected, Activists try to disseminate their own values.

"All the people who come to our shops every day [allows us to] promote ecology, unpolluted soil, that's it." (Executive 12)

It is therefore in the search of products corresponding to their values that Activist SIRs devote most of their energy. These products are made by suppliers with whom Activists share these values. For the Activists, relational interactions with suppliers appear crucial to their competitive strategy, not only for the constitution of their offering, but also for its commercialisation. 
"We are real activists for our winemakers (...) We really work with winemakers who look like us. They are people who struggle and who are passionate, who have no desire at all to damage the Earth." (Executive 19)

Nevertheless, if this competitive strategy materializes in a focus on relations with suppliers, it is based on the values of the executive.

The Visionary SIR. Visionary SIRs are executives who have launched a concept, either to make a living or enrich themselves. This concept aims to exploit a detected business opportunity: a market segment - often local - or a new type of offer seems to have potential in the Visionary SIRs' eyes. Hence the concept has an innovative dimension which aims to reduce competitive intensity by differentiating the company.

"I told myself that I had to be a wine merchant, but a modern wine merchant. It meant to offer home delivery, not necessarily online sales, but home delivery over a rather large area." (Executive 9)

The competitive strategy of Visionary SIRs' does not translate into a focus on one type of interaction with their stakeholders. Instead, what really drives their competitive strategy is their attention to the exploitation of the concept they have designed. The innovative character of the executives seems then to be the key to their strategy. Then, Visionary SIRs can remain Visionary executives if they manage to maintain the innovative dimension of their concept. Otherwise, they may evolve into Classic SIRs, mainly drawing inspiration from their relations with their customers to develop their activities. Executive 2 embodies this possible changeover.

"Once it's launched, it's launched. You follow what the customers want." (Executive 2).

The Skilled SIR. The Skilled SIRs are executives who, before setting up their own businesses, have acquired significant experience in the field in which they operate. This experience allows them to distinguish themselves from their Classic type of competitors by responding more precisely to the customers' needs. 
"And then there are [the wine merchants] like [us] coming from a career of sommelier, but only in Michelin-starred restaurants, so with an extremely demanding business card in wine." (Executive 5)

Sometimes their previous experiences have allowed them to spot a business opportunity to take advantage of.

"[My experience] allowed me to identify, in fact, a market opportunity in France. This is what led me to create [this business]." (Executive 7)

The Skilled SIR leads a thriving business. As Visionaries, Skilled SIRs do not especially focus on any interaction with their stakeholders to drive their business. They do not have to. Their above-theaverage skills allow them to do without a strong customer orientation for example. Customers come to them for their skills, so what they have to do is to harness these skills. Their competitive strategy lies in it.

"On Saturdays, we are the only ones open in the neighbourhood. That absolutely does not prevent us from making our turnover. So, people come, because they know that with us, they will find the product, the advice, etc." (Executive 5)

The Survivor SIR. Survivor SIRs are Classic or Visionary ones who are experiencing difficulties. They somehow manage to face them, but they barely survive.

"We are going to fight all year round not to go on vacation." (Executive 4)

They do not succeed in creating and/or building customer loyalty or capitalizing on their concept. This leads them to adopt a competitive strategy based on reactions to competitors. Concretely, Survivor SIRs observe their competitors to adapt their offer to theirs, not without feeling resentful towards them.

"Right next to us, there is [a disguise store] that has been created. When she arrived, [she told us that she would sell] fancy dresses for adults. Of course, she didn't sell enough costumes for adults, so she made costumes for children. So, the area we had for children's disguises, divided again." (Executive 4) 
As they have difficulties to create a large base of loyal customers, as they don't have the skills that would make this base grow by itself and as they are not innovative enough, they do not have any other choice but to look at what their rivals do. They try to avoid having more difficulties by adapting their offer to avoid unsold stocks. The weight of external factors seems to deprive them of strategic choices.

\section{Discussion}

The discussion section of our paper is divided into two parts. Before discussing the practical implications of our research, addressing future research and study limitations, we try to put our results in literature on SIRs into perspective.

\subsection{Theoretical implications}

A first series of key contributions of this study lies in the identification of 5 types of competitive strategies used by urban SIRs. First, we draw a typology that characterises how SIRs compete, rather than how they face external change (Miles and Snow, 1978; Moore, 2005).

Second, types of SIRs' competitive strategies that remained unknown emerged from this typology. If our Survivor appears similar to Miles and Snow's (1978) reactor, we provide four different types of positive competitive strategies for SIRs. If, as their defender, SIRs adopt a niche strategy (Watkin, 1986), we suggest that there are different ways to do so. SIRs can defend their position by exploiting the innovative concept they created, focusing on customer orientation, selling products in line with the values they intend to spread or taking advantage of their above-the-average skills.

Third, this typology permits to highlight the importance of both the internal factors (Barney, 1991; Peteraf, 1993) and the interactions between firms and their stakeholders (Chen and Miller, 2015) in SIRs' competitive strategies. Indeed, this research shows that SIRs' competitive strategies depend less on the executives' ambition, ability to differentiate their offer, degree of appropriation of the geographic positioning and level of understanding of the market and the environment (Ringwald and Parfitt, 2011), less on their gender (Buttner et Moore, 1997), goals (Reijonen and Komppula, 2007) or human and social capitals (Jones et al., 2010), less on the type of store and its age (Kean et al., 1996), than on their capability to face external factors thanks to their resources. Either SIRs have no weapon to fight against external factors and they suffer competition, or they have limited means and focus on their relationship with customers, or even they possess a specific resource they can rely on (innovative character, skills, values) to go beyond ordinary customer orientation. 
Thus, another implication of this research is the relativisation of the importance given by the literature to customer orientation (Adjei et al., 2009; Tajeddini et al., 2013). It appears to be nothing more than a strategic option. Others remain possible and the longevity of the enterprise of some executives we met shows that those other options can lead SIRs to success as well. Hence our research rather supports studies that emphasised other components of SIRs' prosperity. Our work might even allow to integrate in a coherent corpus most of previous normative researches on the topic of SIRs' performance, all factors of success not being associated to all of the four positive types of the typology. Table 3 presents a possible articulation of the normative works on SIRs' performance.

Table 3. Types of SIR and specific factors of performance (source: authors)

\begin{tabular}{|c|c|c|}
\hline Types of SIR & Factors of performance & Authors \\
\hline \multirow{3}{*}{ All } & Access to financial capital & Grimmer et al., 2018 \\
\hline & Clearly defined strategy & Conant et al., 1993 \\
\hline & Planned strategy & Praharsi et al., 2014 \\
\hline \multirow{2}{*}{ The Activist } & $\begin{array}{l}\text { Proposal of a targeted assortment of } \\
\text { differentiated products }\end{array}$ & Paige and Littrell, 2002 \\
\hline & Relationships with suppliers & Praharsi et al., 2014 \\
\hline \multirow{3}{*}{ The Classic } & Customer orientation & Adjei et al., 2009; Tajeddini et al., 2013 \\
\hline & Customer service & $\begin{array}{l}\text { Ellis and Kelley, 1992; Merlo et al., } \\
\text { 2006; Paige and Littrell, } 2002\end{array}$ \\
\hline & Loyalty program & Praharsi et al., 2014 \\
\hline The Skilled & $\begin{array}{l}\text { Knowledge allowing to obtain supplies } \\
\text { from quality suppliers }\end{array}$ & McGuiness and Hutchinson, 2013 \\
\hline The Visionary & Innovation & Bhaskaran, 2006; Lin, 2016 \\
\hline
\end{tabular}

4.2. Practical implications, future research and limitations

This research has potential for important practical implications. First of all, it could be useful for executives. The typology could be seen as a user-friendly tool for them to better understand their competitive strategies and its factors of performance. From that, they could adjust their competitive strategy. For example, Visionary SIRs' competitive strategy may be impacted by the arrival of direct competitors. Having in mind the risks associated to their strategy, they might consider other ways to conquer and retain their customers, for example developing their competences. Survivor SIRs could also take full advantage from this typology, which provides them with different ways to get out of their difficulties. Besides, this research could help municipalities which are seeking to revitalise their city centres or simply develop a commercial area. This typology could guide them to better select 
SIRs who want to start a business in the target area and to better support them once it has been launched. In such cases, the candidates with expertise gained from past experiences seem to have the potential to better meet the customers' needs and, as a consequence, to last over time. All SIRs would benefit from trainings aiming to upgrade their skills that could be offered by municipalities or professional organisations.

This research is nevertheless not free from limitations. First, we attempted to organize previous work on SIRs' performance even if in our own research we did not measure performance otherwise than in the survival of the executives' businesses. Further research could thus be conducted to better understand factors of performance for each type of SIR. We could also wonder if some types of SIRs are more successful than others.

Second, we did not take vertical competition into account. It did not emerge from our study as the SIRs we met benefit from a favourable balance of power against their very numerous suppliers. The context of this research was not conducive to long speeches on supplier relations, so further research in contexts of higher vertical competition is required to see if SIRs would take better account of them, reducing again the focus on customer orientation in their competitive strategies.

Third, it is important to note that the results might be limited to our specific context. This study was conducted in the close suburbs of Paris and findings might be different in booming or declining areas. For example, we could wonder whether the Survivor type of SIR could survive in more difficult environments. Further research in declining contexts would benefit to municipalities of small and medium-sized cities aiming to revitalise their city centres. Moreover, the results may be other in countries with different retail structure. SIRs still represent $10 \%$ of French retail (Badot et al., 2018), it could be interesting for both policy makers and practitioners to know which types of SIRs are left in countries where they are less numerous.

\section{Conclusion}

The aim of this study was to identify the competitive strategies urban SIRs adopt to face the multiple forms of competition they have to deal with. The question arose from the fact that despite the important part played by SIRs in city centres revitalisation (Padilla and Eastlick, 2009), little knowledge exists about their actual competitive strategies.

This research extends literature through the typology based on the actual competitive strategies of SIRs that we built. This very first typology of SIRs draws five types of SIRs and reveals that other strategic options than customer orientation are used. Indeed, some SIRs focus on exploiting their 
above-the-average skills or their innovative concept, while some others concentrate on their relationships with suppliers to be able to find and sell goods corresponding to their values.

This typology might become a useful tool for SIRs interested in competitive strategies and for municipalities looking for new insights to succeed in the revitalisation of their city centres. In addition, it seems to be a potential integrator for researches about the performance of SIRs' competitive strategies.

Further research is nevertheless required to better understand the relations between the five types of SIR and their performance and to see how our types of SIR evolve in different environments.

\section{References}

Adjei, M.T., Griffith, D.A. and Noble, S.M. (2009), "When do relationships pay off for small retailers? Exploring targets and contexts to understand the value of relationship marketing”, Journal of Retailing, Vol. 85 No. 4, pp. 493-501.

Armstrong, C.E. (2012), "Small retailer strategies for battling the big boxes: a 'Goliath' victory?", Journal of Strategy and Management, Vol. 5 No. 1, pp. 41-56.

Armstrong, S.J. and Hird, A. (2009), "Cognitive style and entrepreneurial drive of new and mature business owner-manager", Journal of Business Psychology, Vol. 24 No. 4, pp. 419-430.

Badot, O., Lemoine, J.F. and Ochs, A. (2018), Distribution 4.0, Pearson, Montreuil.

Barber, C.S., and Tietje, B.C. (2004), "A distribution services approach for developing effective competitive strategies against 'Big Box' retailers", Journal of Retailing and Consumer Services, Vol. 11 No. 2, pp. 95-107.

Barney, J.B. (1991), "Firm resources and sustained competitive advantage", Journal of Management, Vol. 17 No. 1, pp. 99-120.

Bessière, S. and Trevien, C (2016), "Le commerce de centre-ville: une vitalité souvent limitée aux grandes villes et aux zones touristiques", Insee Références, available at: https://www.insee.fr/fr/statistiques/2497068?sommaire=2497179 (accessed 13 February 2020).

Bhaskaran, S. (2006), “Incremental innovation and business performance: small and medium-size food enterprises in a concentrated industry environment", Journal of Small Business Management, Vol. 44 No. 1, pp. 64-80.

Bicard, D. (2019), "L'activité du commerce spécialisé chute de 3,3\% en 2018”, LSA, available at: https://www.lsa-conso.fr/l-activite-du-commerce-specialise-chute-de-3-3-sur-1-annee-2018procos,308561 (accessed 13 February 2020). 
Buttner, E.H. and Moore, D.P. (1997), “Women's organizational exodus to entrepreneurship: Selfreported motivations and correlates with success”, Journal of Small Business Management, Vol. 35 No. 1, pp. 34-46.

Chen, M.J. and Miller, D. (2012), "Competitive dynamics: Themes, trends, and a prospective research platform”, The Academy of Management Annals, Vol. 6, No 1, pp. 135-210.

Chen, M.J. and Miller, D. (2015), "Reconceptualizing competitive dynamics: A multidimensional framework", Strategic Management Journal, Vol. 36, No 5, pp. 758-775.

Chocron, V. (2020), “A Alençon, la rue aux Sieurs, symbole de la lente agonie des centres-villes”, Le Monde, available at: https://www.lemonde.fr/economie/article/2020/08/29/a-alencon-la-rue-auxsieurs-symbole-de-la-lente-agonie-des-centres-villes_6050262_3234.html (accessed 28 September 2020).

Coca-Stefaniak, J.A., Parker, C. and Rees, P. (2010), “Localisation as a marketing strategy for small retailers", International Journal of Retail \& Distribution Management, Vol. 38 No. 9, pp. 677-697.

Conant, J.S., Smart, D.T. and Solano-Mendez, R. (1993), "Generic retailing type distinctive marketing competencies and competitive advantage”, Journal of Retailing, Vol. 69 No. 3, pp. 254279.

Cossette, P. (2002), “Analysing the thinking of F.W. Taylor using cognitive mapping", Management Decision, Vol. 40 No. 2, pp. 168 - 182.

D'Aveni, R.A. (1994), Hypercompetition: Managing the dynamics of strategic maneuvering, The Free Press, New York.

Delage, M., Baudet-Michel, S., Fol, S., Buhnik, S., Commenges, H. And Vallée, J. (2020), "Retail decline in France's small and medium-sized cities over four decades: Evidences from a multi-level analysis", Cities, Vol. 104, 102790.

Eden, C. (2004), “Analyzing cognitive maps to help structure issues or problems”, European Journal of Operational Research, Vol. 159 No. 3, pp. 673-686.

Ellis, B. and Kelley, S.W. (1992), "Competitive advantage in retailing”, International Review of Retail, Distribution and Consumer Research, Vol. 2 No. 4, pp. 381-397.

Erkip, F. and Ozuduru, B.H. (2015), "Retail development in Turkey: An account after two decades of shopping malls in the urban scene", Progress in Planning, Vol. 102, pp. 1-33.

Fassin, Y., Van Rossem, A. and Buelens, M. (2011), “Small-business owner-managers' perceptions of business ethics and CSR-related concepts”, Journal of Business Ethics, Vol. 98 No. 3, pp. 425453. 
Glaser, B.G. and Strauss, A.L. (1967), The discovery of grounded theory: Strategies for qualitative research, Aldine, Chicago.

Grimmer, L., Grimmer, M. and Mortimer, G. (2018), “The more things change the more they stay the same: a replicated study of small retail firm resources", Journal of Retailing and Consumer Services, Vol. 44, pp. 54-63.

Janssen, S., Tahitu, J., VanVuuren, M. and DeJong, M.D.T. (2018), “Coworkers' Perspectives on Mentoring Relationships", Group \& Organization Management, Vol. 43, No. 2, pp. 252-272.

Jones, O., Macpherson, A. and Thorpe, R. (2010), "Learning in owner-managed small firms: Mediating artefacts and strategic space", Entrepreneurship \& Regional Development, Vol. 22 No. 7-8, pp. 649-673.

Hallsworth, A.G. and Coca-Stefaniak, J.A. (2018), "National high street retail and town centre policy at a cross roads in England and Wales", Cities, Vol. 79, pp. 134-140.

Kajalo, S. and Lindblom, A. (2015), "Market orientation, entrepreneurial orientation and business performance among small retailers", International Journal of Retail \& Distribution Management, Vol. 43 No. 7, pp. 580-596.

Kara, A., Spillan, J.E. and DeShields, Jr, O.W. (2005), "The effect of market orientation on business performance: a study of small-sized service retailers using MARKOR scale”, Journal of Small Business Management, Vol. 43 No. 2, pp. 105-118.

Kean, R.C., Niemeyer, S. and Miller, N.J. (1996), “Competitive strategies in the craft product retailing industry", Journal of Small Business Management, Vol. 34 No. 1, pp. 13-23.

Kfoury, J. and Trevien, C. (2017), "Les points de vente du commerce de détail”, Insee Première, No. 1668, available at: https://www.insee.fr/fr/statistiques/3126810 (accessed 13 February 2020).

Kim, W., Hallsworth, A. and Kim, H. (2018), "Examining the effectiveness of government policy for retail districts: Evidence from Korea", Sustainability, Vol. 10, No 5, 1558.

Kotler, P. (2003), Marketing Management, Prentice Hall, Upper Saddle River, NJ.

Lesnes, C. (2020), “Aux États-Unis, le commerce de détail en pleine 'apocalypse'”, Le Monde, available at: https://www.lemonde.fr/economie/article/2020/01/27/aux-etats-unis-le-commercede-detail-en-pleine-apocalypse_6027308_3234.html (accessed 13 February 2020).

Li, J., Hallsworth, A.G. and Coca-Stefaniak, J.A. (2020), "Changing Grocery Shopping Behaviours Among Chinese Consumers at The Outset of the COVID-19 Outbreak", Tijdschrift voor economische en sociale geografie, Vol. 111, No 3, pp. 574-583.

Lin, C.-Y. (2016), "Perceived convenience retailer innovativeness: how does it affect consumers?", Management Decision, Vol. 54 No. 4, pp. 946-964. 
McGuiness, D. and Hutchinson, K. (2013), "Utilising product knowledge. Competitive advantage for specialist independent grocery retailers", International Journal of Retail \& Distribution Management, Vol. 41 No. 6, pp. 461-476.

Megicks, P. and Warnaby, G. (2008), "Market orientation and performance in small independent retailers in the UK", The International Review of Retail, Distribution and Consumer Research, Vol. 18 No. 1, pp. 105-119.

Merlo, O., Bell, S.J., Menguc, B. and Whitwell, G.J. (2006), "Social capital, customer service orientation and creativity in retail stores", Journal of Business Research, Vol. 59 No. 12, pp. 12141221.

Miles, M.B., Huberman, A.M. and Saldana, J. (2019), Qualitative Data Analysis: A Methods Sourcebook ( $4^{\text {th }}$ edition $)$, Sage, London.

Miles, R.E. and Snow, C.C. (1978), Organizational Strategy, Structure, and Process, McGraw-Hill, New-York.

Moati, P. (2016), "Vers la fin de la grande distribution ?", Revue Française de Socio-Économie, Vol. 16 No. 1, pp. 99-118.

Moore, M. (2005), “Towards a confirmatory model of retail strategy types: an empirical test of Miles and Snow", Journal of Business Research, Vol. 58, No 5, pp. 696-704.

Padilla, C. and M.A. Eastlick (2009), "Exploring urban retailing and CBD revitalization strategies", International Journal of Retail \& Distribution Management, Vol. 37 No. 1, pp. 7-23.

Paige, R.C. and Littrell, G.A. (2002), “Craft retailers' criteria for success and associated business strategies", Journal of Small Business Management, Vol. 40 No. 4, pp. 314-331.

Patton, M.Q. (2015), Qualitative research and evaluation methods (4 ${ }^{\text {th }} \mathrm{ed}$.), Sage, Los Angeles.

Pekovic, S. and Rolland, S. (2016), “Customer orientation and firm's business performance: A moderated mediation model of environmental customer innovation and contextual factors", European Journal of Marketing, Vol. 50 No. 12, pp. 2162-2191.

Pelham, A.F. (2000), "Market orientation and other potential influences on performance in small and medium-sized manufacturing firms", Journal of Small Business Management, Vol. 38 No. 1, pp. 48-67.

Peteraf, M.A. (1993), “The cornerstone of competitive advantage”, Strategic Management Journal, Vol. 14 No. 3, pp. 179-191.

Porter, M.E. (1980), Competitive Strategy, The Free Press, New York.

Praharsi, Y., Wee, H.-M., Sukwadi, R. and Padilan, M.V. (2014), “Small-independent retailers vs. organized retailers: An empirical study in Indonesian economics of service industries", Journal of Retailing and Consumer Services, Vol. 21 No. 2, pp. 108-117. 
Reijonen, I. and Komppula, R. (2007), "Perception of Success and its Effect on a Small Firm Performance", Journal of Small Business and Enterprise Development, Vol. 14 No. 4, pp. 689701.

Ringwald, K. and Parfitt, S. (2011), "Is reflective practice the key to survival for small independent retailers? Evidence from South-East Wales”, Reflective Practice, Vol. 12 No. 5, pp. 585-598.

Runyan, R.C. and Droge, C. (2008), “A categorization of small retailer research streams: What does it portend for future research?", Journal of Retailing, Vol. 84 No. 1, pp. 77-94.

Slater, S.F. and Narver, J.C. (1994), "Does competitive environment moderate the market orientation performance relationship?", Journal of Marketing, Vol. 58 No. 1, pp. 46-55.

Smith, K.G., Guthrie, J.P. and Chen, M.-J. (1986), "Strategy, size and performance”, Organization Studies, Vol. 10, No 1, pp. 63-81.

Spillan, J. and Parnell, J. (2006), "Marketing resources and firm performance among SMEs", European Management Journal, Vol. 24 No. 2-3, pp. 236-245.

Tajeddini, K., Elg, U. and Trueman, M. (2013), "Efficiency and effectiveness of small retailers: The role of customer and entrepreneurial orientation", Journal of Retailing and Consumer Services, Vol. 20 No. 5, pp. 453-462.

Vargo, S.L. and Lusch, R.F. (2004), "Evolving to a new dominant logic for marketing”, The Journal of Marketing, Vol. 68 No. 1, pp. 1-17.

Watkin, D.G. (1986), “Toward a competitive advantage: A focus strategy for small retailers”, Journal of Small Business Management, Vol. 24 No. 1, pp. 9-15.

Watts, H.D., Wood, A.M. and Wardle, P. (2006), “Owner-managers, clusters and local embeddedness: Small firms in the Sheffield (UK) metal-working cluster", Entrepreneurship \& Regional Development, Vol. 18 May, pp. 185-205.

Yin, R.K. (2012), Applications of Case Study Research, Sage, Thousand Oaks. 